\title{
Nineteenth century collections of Pterygotus anglicus Agassiz (Chelicerata; Eurypterida) from the Campbellton Formation, New Brunswick, Canada
}

\author{
Randall F. Miller \\ Steinhammer Palaeontology Laboratory, Natural Science Department, New Brunswick Museum, \\ Saint John, New Brunswick E2K 1E5, Canada <Randall.Miller@nbm-mnb.ca >
}

Date received: 14 December 2006 Date accepted: 21November 2007

\begin{abstract}
The Devonian fauna from the Campbellton Formation of northern New Brunswick was discovered in 1881 at the classic locality in Campbellton. About a decade later A.S. Woodward at the British Museum(Natural History) (now the Natural History Museum, London) acquired specimens through fossil dealer R.F. Damon. Woodward was among the first to describe the fish assemblage of ostracoderms, arthrodires, acanthodians and chondrichthyans. At the same time the museum also acquired specimens of a large pterygotid eurypterid. Although the vertebrates received considerable attention, the pterygotids at the Natural History Museum, London are described here for the first time. The first pterygotid specimens collected in 1881 by the Geological Survey of Canada were later identified by Clarke and Ruedemann in 1912 as Pterygotus atlanticus, although they suggested it might be a variant of Pterygotus anglicus Agassiz. An almost complete pterygotid recovered in 1994 from the Campbellton Formation at a new locality in Atholville, less than two kilometres west of Campbellton, has been identified as P. anglicus Agassiz. Like the specimens described by Clarke and Ruedemann, the material from the Natural History Museum, London is herein referred to P. anglicus.
\end{abstract}

\section{RÉSUMÉ}

La faune dévonienne de la Formation de Campbellton dans le Nord du Nouveau-Brunswick a été découverte en 1881 à l'emplacement classique de Campbellton. Environ une décennie plus tard, A. S. Woodward, du British Museum (Histoire naturelle) (maintenant le Natural History Museum de Londres) a fait l'acquisition de spécimens par l'entremise du négociant de fossiles R. F. Damon. Woodward a figuré parmi les premiers à décrire l'assemblage de poissons d'ostracodermes, d'arthrodires, d'acanthodiens et de chondrichthyens. Le musée a également fait en même temps l'acquisition de spécimens d'un euryptéridé ptérygotide de fortes dimensions. Même si les vertébrés ont bénéficié d'une attention considérable, les ptérygotides du Natural History Museum de Londres sont décrits aux présentes pour la première fois. Les premiers spécimens de ptérygotides recueillis en 1881 par la Commission géologique du Canada ont ultérieurement été identifiés par Clarke et Ruedemann en 1912 en tant que Pterygotus atlanticus, bien que les chercheurs aient avancé qu'il pourrait s'agir d'une variante du Pterygotus anglicus Agassiz. On a récupéré en 1994 un ptérygotide presque complet de la Formation de Campbellton dans un nouvel emplacement situé à Atholville, à moins de deux kilomètres à l'ouest de Campbellton, lequel a été identifié en tant que P. anglicus Agassiz. À l'instar des spécimens décrits par Clarke et Ruedemann, l'article du Natural History Museum de Londres est cité aux présentes à titre de P. anglicus.

[Traduit par la redaction]

\section{INTRODUCTION}

The Campbellton Formation exposed at Campbellton, New Brunswick (Fig. 1), has been known for the fauna of ostracoderms, arthrodires, acanthodians and chondrichthyans (Whiteaves 1881, 1889; Woodward 1889, 1892; Traquair 1890, 1893) since the first vertebrate fossils were discovered in 1881 (Whiteaves 1899). Dineley and Williams (1968) called the vertebrate-bearing part of the formation the 'Atholville beds'. In addition to fish, the assemblage includes ostracods (Jones
1889), molluscs (Whiteaves 1881), and eurypterids (Whiteaves 1881; Clarke and Ruedemann 1912). Plants have also been identified from the Campbellton locality (Gensel and Albright 2006). The Campbellton Formation east of Campbellton, from Dalhousie Junction to Point Pin Sec (Fig. 1A), has not yielded vertebrates, but since the mid-1800's has produced a rich flora of zosterophyllophytes, trimerophytes and lycopsids (Gensel and Andrews 1984; Gensel et al. 1991). Recently an assemblage of terrestrial arthropods, including Eoarthropleura devonica and scorpion remains (Shear et al. 1996), and the millipede 
Gaspestria genselorum (Wilson 2006) has been identified near the Dalhousie Junction and Point la Nim areas (Fig. 1A). West of Campbellton at Atholville (Fig. 1B), the Atholville beds examined since 1994 have produced remains of chondrichthyans (Miller et al. 2003), ostracoderms, arthrodires, acanthodians and pterygotid eurypterids (Miller 1996, 2007).

Pterygotids, which can reach more than two metres in length (Kjellesvig-Waering 1964; Chlupáč 1994), are relatively rare in the fossil record. The Pterygotoidea is believed to be the most cosmopolitan of the eurypterid clades (Tetlie 2007). It is also the most diverse with 56 species, although Tetlie (2007) believed the clade might be oversplit. Whiteaves (1881), at the Geological Survey of Canada, was the first to note Pterygotus sp. in the Lower Devonian Campbellton Formation from the Campbellton locality (Fig. 1B). His specimens (GSC 3239, 3239a-c; Bolton 1966) were later described as P. atlanticus by Clarke and Ruedemann (1912, p. 358) who considered their new species to be "of considerable dimensions" and compared

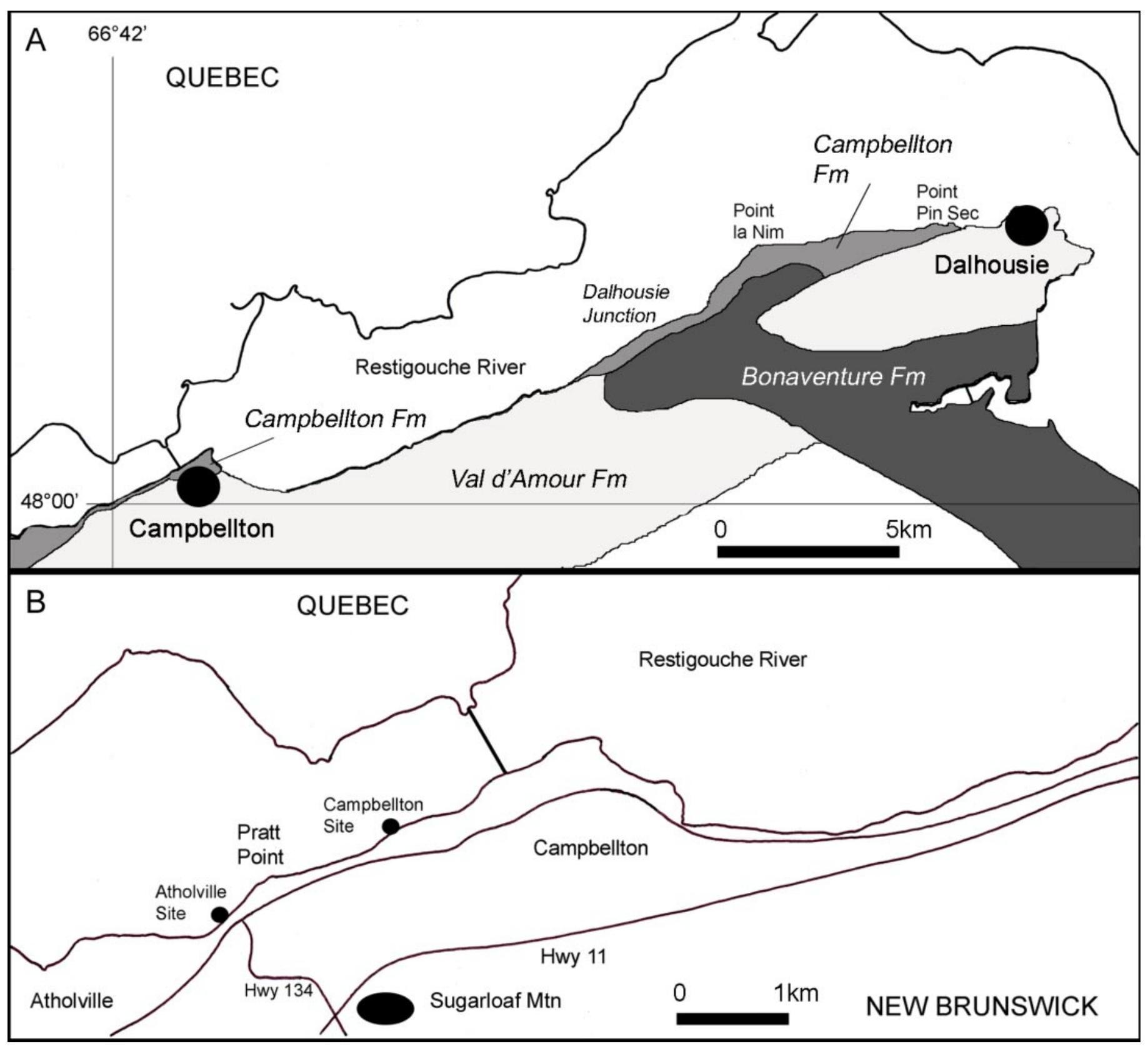

Fig. 1 Location and geology map of the Atholville and Campbellton sites. A) Geology along the New Brunswick shore of the Restigouche River showing approximate extent of the Val d'Amour Formation, Campbellton Formation, and Bonaventure Formation (after Wilson et al. 2004); B) Detail of the Campbellton area showing the location of fossil sites at Campbellton and Atholville. Fossil-bearing rocks outcrop intermittently along the shore between the sites indicated. 
it to Pterygotus anglicus Agassiz, 1844. They suggested that with larger collections the species might prove to be "a vicarious form" of P. anglicus, the type species of the genus from the Early Devonian of Scotland (Agassiz 1844; Huxley and Salter 1859; Woodward 1866-78; Kjellesvig-Waering 1964; Waterston 1964). Pageau (1969a) briefly mentioned finding pterygotid fragments associated with fish fossils from Campbellton.

This paper describes for the first time, pterygotid eurypterid fossils collected in the late 1800's from the base of the Campbellton Formation exposed at the classic Campbellton locality (Fig. 1B), and reposited in the Natural History Museum, London (NHM I and NHM In). Although there are more than 40 specimens, a large collection for the Maritime Provinces of eastern Canada, little attention has been paid to them. In 1889, A.S. Woodward $(1889,1892)$ began to describe the fish fossils from Campbellton acquired by the British Museum (Natural History) (now the Natural History Museum, London) through fossil dealer R.F. Damon. Along with fish, Damon supplied pterygotid specimens in 1888, 1892 and 1893 . One specimen, NHM In.18520, was later identified as Pterygotus atlanticus Clarke and Ruedemann (NHML specimen label notation by E.N. Kjellesvig-Waering), but otherwise the specimens have been identified only as Pterygotus sp. The National Museums of Scotland (NMS) also purchased a collection of Campbellton specimens from Damon in 1897 that included 12 small fragments with pterygotid remains; about half are undiagnostic cuticle fragments. Traquair $(1890,1893)$, at the museum in Edinburgh, also described vertebrates from the Campbellton locality.

\section{LOCATION AND GEOLOGY}

The Devonian Campbellton Formation (Williams et al. 1985; Wilson et al. 2004; New Brunswick Department of Natural Resources 2007) is exposed along the banks of the Restigouche River-Bay of Chaleur, New Brunswick, Canada from Atholville in the west to its eastern limit near Dalhousie (Fig. 1A). The Campbellton Formation unconformably overlies rhyolite of the Lower Devonian Val d'Amour Formation of the Dalhousie Group (Wilson et al. 2004). Dineley and Williams (1968) referred to the vertebrate-bearing beds, outcropping for almost $2 \mathrm{~km}$ on the south shore of the Restigouche River from Campbellton to Atholville, as the 'Atholville beds' (Fig. 1B). They are comprised of a steeply inclined basal coarse breccia overlain by a succession of interbedded sandstones and mudstones (Fig. 2). Published descriptions (Whiteaves 1881) and specimen labels indicate collections of fish and eurypterids from the late 1800's were all made toward the Campbellton end of the Atholville beds, east of Pratt Point (Fig. 1B) where the fossil-bearing unit today only consists of a thin veneer of mudstone overlying the irregular surface of a steep rhyolite cliff face. The basal fossil-bearing sediments display no clear bedding.

Most specimens supplied to the Natural History Museum, London and the National Museums of Scotland occur in a grey

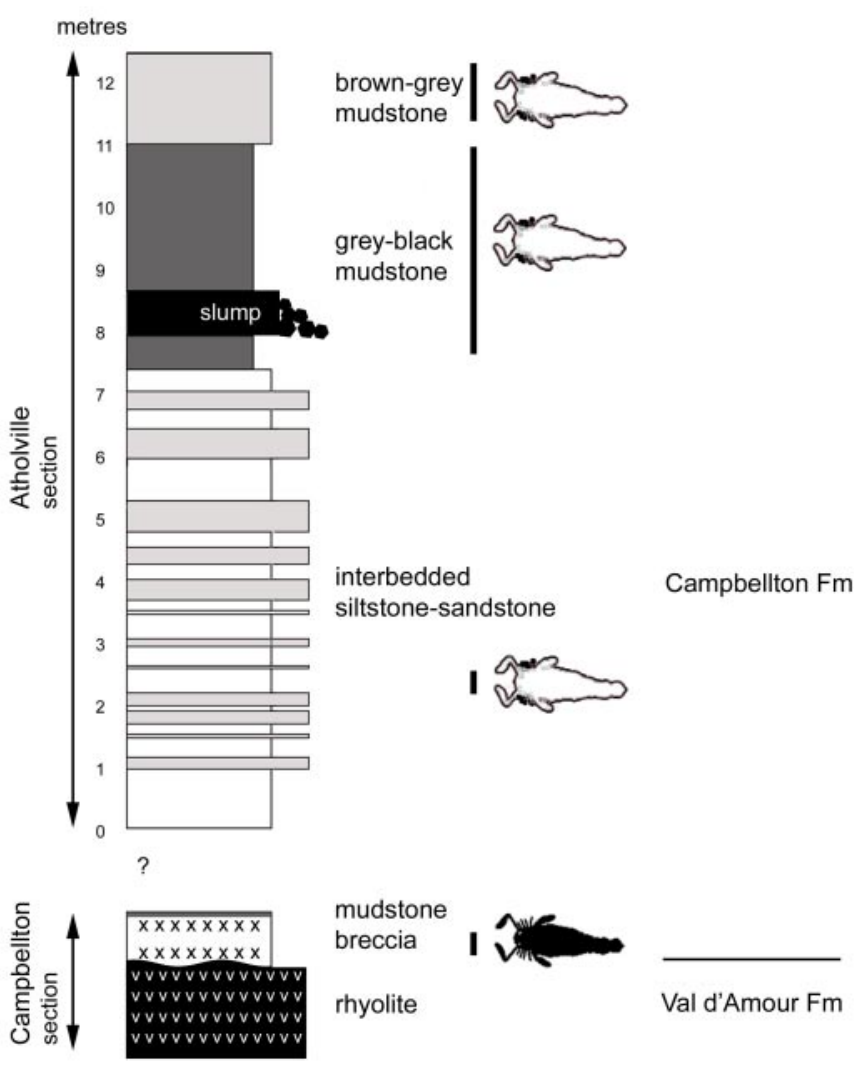

Fig. 2 Schematic stratigraphic column for the Atholville beds of the Campbellton Formation showing distribution of pterygotid eurypterids at localities in Campbellton (black) and Atholville (white). The Atholville beds are composed of a steeply inclined basal coarse mudstone breccia resting on rhyolite and overlain by a succession of interbedded sandstones and mudstones. Most pterygotid specimens described here were likely derived from a mudstone layer overlying the breccia at Campbellton.

mudstone rich in ostracods and gastropods, and sometimes containing volcanic clasts. Three of the pterygotid specimens described by Whiteaves (1881) at the Geological Survey of Canada are in a dark grey breccia of mudstone and rhyolite. Similar rocks occur in Campbellton just above the Val d'Amour Formation rhyolite, but are not seen above the rhyolite in outcrops at Atholville. Sampling of the eastern-most exposure of the formation at Campbellton $\left(48^{\circ} 00.13 \mathrm{~N} ; 66^{\circ} 41.68 \mathrm{~W}\right)$ has yielded fish and rare eurypterid remains in the breccia immediately overlying the Val d'Amour Formation, suggesting this may be the source of some specimens at the Natural History Museum, London. Most NHM specimens are not in the breccia and likely came from an overlying mudstone presumably depleted by early collectors. The mudstone breccia overlying the rhyolite appears to be locally deposited and may not form the basal unit of the entire Atholville beds of Dineley and Williams (1968). Slumping, industrial debris and vegetation obscure much of the outcrop. 
Palynological data date the Campbellton Formation as Emsian (Blieck and Cloutier 2000). Richardson and McGregor (1986) identified the Emphanisporites annulatusCamarozonotriletes sextantii miospore Assemblage Zone which approximately corresponds to the Polygnathus dehiscens to $P$. serotinus Conodont Zones of early Emsian to early late Emsian age (Blieck and Cloutier 2000). McGregor $(1973,1977)$ placed the outcrops along the Restigouche River within the Pragian "caperatus-emsiensis" and early to late Emsian spore zones, "sextantii-Grandispora" to "annulatus-lindlarensis". The Pterygotus-bearing beds are near the base of the Campbellton Formation, probably within the early Emsian, not far above the Pragian-Emsian boundary stratotype age at $407 \pm 2.8 \mathrm{Ma}$ (Ogg 2004).

Wilson et al. (2004) recognized an angular unconformity separating the Val d'Amour and Campbellton formations and suggested the Campbellton Formation straddled the EmsianEifelian boundary stratotype age at $397.5 \pm 2.7 \mathrm{Ma}$ (Ogg 2004). Their interpretation is based on a radiometric date of 407.4 $\pm 0.8 \mathrm{Ma}$ in the Val d'Amour Formation (Fig. 1A) comprised of mafic to felsic volcanic rocks and minor sediments (Wilson et al. 2004). Reexamination of the contact, following the publication of Wilson et al. (2004), suggests perhaps a closer relationship than interpreted by these authors between the Val d'Amour Formation rhyolite and the Campbellton Formation sediments, consistent with palynological data. Some authors (Pageau 1968, 1969a, b) have considered the Campbellton outcrops equivalent to the Battery Point Formation or the LaGarde and Pirate Cove formations (Wilson et al. 2004; Bourque et al. 2005) found north of the Bay of Chaleurs in Gaspé, Quebec.

\section{SYSTEMATIC PALEONTOLOGY}

Dunlop et al. (2002) briefly discussed eurypterid systematics and recognized that a number of problems exist due in part to a large number of taxa based on incomplete or even nondescript fossils. They published a provisional cladogram with suggested synapomorphies for a selected set of taxa including Pterygotus. More recently Ciurca and Tetlie (2007) and Tetlie (2007) have reviewed eurypterid phylogeny and provided an updated cladogram. Miller (2007) provided an emended diagnosis for Pterygotus anglicus with additional details concerning the chelicera, considered one of the key diagnostic structures to distinguish species of pterygotids. Tollerton(1989) provided a summary of terminology to describe and differentiate eurypterids. Diagnoses below are a composite of descriptions applied to the Family and species description of Pterygotus anglicus.

\section{Family PTERYGOTIDAE Clarke and Ruedemann, 1912}

Diagnosis. Prosoma with large, ovoid, marginal eyes; ventral shield or doublure broad; chelicera large and very long with numerous large denticles; walking legs very slender, cylindrical without spines; swimming paddle proportionately small; genital appendage unsegmented, type A appendage spatulate or club-shaped, type B appendage expanded elliptical or diamond-shaped; metastoma ovoid, cordate or notched anteriorly; opisthosoma without constriction; telson paddle-shaped; surface sculpture consisting of large squamous ornamentation. Emended from Kjellesvig-Waering (1961) and Waterston (1964).

\section{Genus PTERYGOTUS Agassiz, 1839}

Diagnosis. Pterygotidae of large size, with a subtrapezoid prosoma; free ramus of chelicera terminating in a curved denticle; denticles curved posteriorly, without marginal serrations; metastoma ovoid, cordate anteriorly, wide; genital appendage type A spatulate or club-shaped, type B simple; elliptical, expanded telson terminating in a spine; coxa of swimming leg with twelve gnathobasic denticles; pretelson more or less expanded; telson with dorsal carina. Emended from Størmer (1936), Kjellesvig-Waering (1961) and Waterson (1964).

\section{Pterygotus anglicus Agassiz, 1844 Figures 3-9}

Diagnosis. Fixed and free rami with terminal denticles curved, and perpendicular to slightly inclined; terminal denticle of the fixed ramus encloses the terminal denticle of free ramus; fixed ramus and free ramus possess a large primary denticle; primary and intermediate denticles inclined slightly posteriorly on the free ramus and perpendicular or inclined slightly posteriorly on the fixed ramus; primary denticle on the fixed ramus may be inclined slightly anteriorly in front of the primary denticle on the free ramus; denticles are longitudinally striated.

1881 Pterygotus sp. Whiteaves, p. 100.

1883 Pterygotus sp. Ells, p. 10D.

1912 Pterygotus atlanticus Clarke and Ruedemann, p. 356, pl. 79, figs. 3-5.

1960 Pterygotus sp. Copeland and Bolton, p. 44 (in part).

1960 Pterygotus atlanticus Copeland and Bolton, p. 44.

1964 Pterygotus atlanticus Kjellesvig-Waering, p. 344.

1969a Pterygotus sp. Pageau, p. 402.

2007 Pterygotus anglicus Miller, p. 986, pl. 1, figs. 4-12, 14.

Material: Fossils described are from the collections of the Natural History Museum, London (NHM) and the National Museums of Scotland (NMS), purchased from R.F. Damon. Specimens NHM I.3207, I.3208, I.3210 were purchased in 1888; specimens NHM In.59030-32, In.59034, In.59036-46, In.59048-50, In.59052-64 were purchased in 1892; and NHM In.18520 was purchased in 1893. Some numbers are used for more than one slab. Specimens NMS 1897.51.2 to 1897.51.13 were purchased in 1897. Most fossils are in a dark grey to black mudstone, rich in ostracods, commonly with plant fragments and fish remains (acanthodian scales and spines, placoderm plates and less commonly shark teeth and scales). 
Description: Specimens in the NHM collection likely represent at least three separate animals, preserved as partial prosomal and opisthosomal segments. Fragments of chelicerae, coxa of the swimming leg, endognath, opisthosomal segments, pretelson and telson are preserved. Terms used in description are illustrated in Fig. 4B.

Carapace: Three partial carapace of the prosoma, along with portions of the opisthosoma, are preserved. NHM In.5905059055-59064 and their counterparts NHM In.59058-59064 preserve an almost complete carapace, coxa and opisthosomal segment 7(?) (Fig. 3A). The carapace is relatively smooth (Fig. $3 \mathrm{~B})$. It is distorted, but is approximately $129 \mathrm{~mm}$ long and 176 mm wide at the ocelli, likely subquadratic in shape (Tollerton 1989), with a lateral angle of approximately 77 degrees (Fig. 3c). One oval eye (Fig. 3D), approximately $33 \mathrm{~mm}$ long and $27 \mathrm{~mm}$ wide, is positioned antelaterally (Tollerton 1989).

NHM In.59057 preserves a half carapace and part of opist- hosomal segments 1-4 (Fig. 4A, B). It is approximately $103 \mathrm{~mm}$ long and $125 \mathrm{~mm}$ wide at the ocelli, possibly subquadratic in shape (Tollerton 1989). A poorly preserved, oval eye, approximately $28 \mathrm{~mm}$ long and $25 \mathrm{~mm}$ wide, is positioned antelaterally to antemesially (Tollerton 1989). NHM In.59056 preserves a partial carapace and part of opisthosomal segments 1-7(?).

Chelicerae: A number of partial chelicerae are preserved (NHM In.59030/In.59032/In.59033/In.59035/In.59039-In.59046/ In.59042/ In.59045/ In.59047/ In.59051/ In.59054). None are preserved as complete elements making it difficult to reconstruct an entire chelicera (Fig. 5). A reconstruction of the chelicera of $P$. anglicus (Fig. 6) based on specimens from the Atholville site (Miller 2007) indicates a primary denticle (d1) flanked by up to three intermediate denticles ( $\mathrm{d} 2$ to $\mathrm{d} 4)$ between $\mathrm{d} 1$ and the terminal denticle $(\mathrm{td})$ and one or two (perhaps more) intermediate denticles $(\mathrm{d} 6, \mathrm{~d} 7)$ on the proximal side of d1. Smaller denticles occur between the $\mathrm{d} 1$ and $\mathrm{d} 7$ denticles and
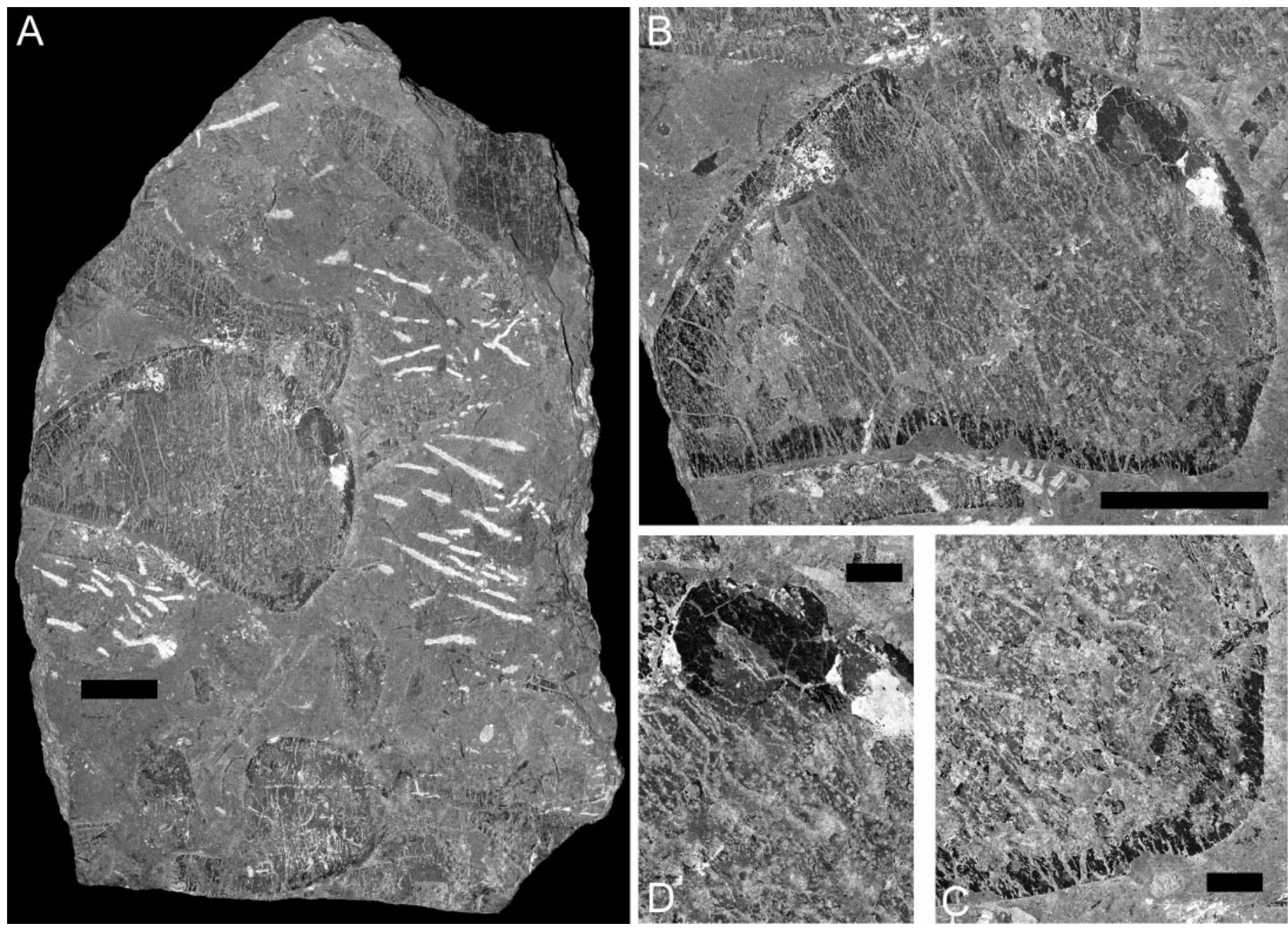

Fig. 3 Pterygotus anglicus Agassiz, 1844. A) Slab containing carapace, coxa and opisthosomal segment, $s c a l e=5 \mathrm{~cm} ; \mathrm{B}$ ) Partial carapace NHM In.59064, scale $=5 \mathrm{~cm}$; C) Closeup of genal angle of NHM In.59064, scale =1 cm; D) Closeup of eye of NHM In.59064, scale $=1 \mathrm{~cm}$. Campbellton Formation, Campbellton, New Brunswick. 
along the free ramus where it is inserted into the fixed ramus (NHM In.59051). Denticles are not inclined but perpendicular to the ramus. Specimen NHM In.59039 (Fig. 5A) illustrates a primary denticle (d1) with two intermediate denticles ( $\mathrm{d} 3$ and d4) toward the distal end. NHM In.59032 (Fig. 5B) illustrates a curved terminal denticle (td). Other NHM specimens listed above demonstrate characters consistent with P. anglicus. NMS 1897.51.13 preserves a primary denticle.

Appendages: NHM In.59058-59064 (part and counterpart) preserves an almost complete coxa of a swimming leg (Fig. $7 \mathrm{~A})$. The gnathobase is truncated with only six denticles vis-
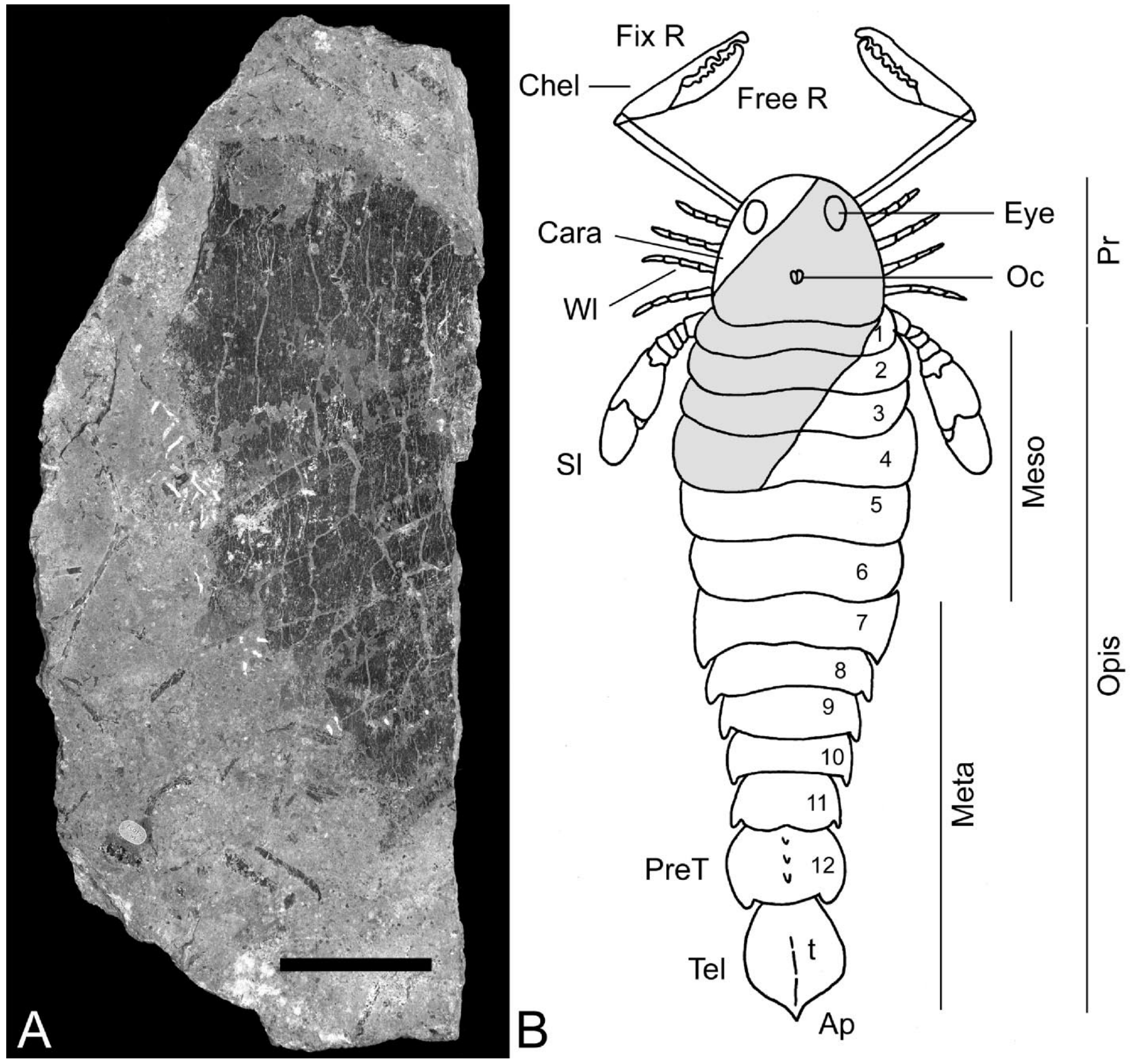

Fig. 4 Pterygotus anglicus Agassiz, 1844. A) Carapace and segments 1-4? of opisthosoma NHM In.59057, Campbellton Formation, Campbellton, New Brunswick, scale $=5 \mathrm{~cm}$; B) Pterygotid schematic highlighting area preserved on NHM In.59057 (reversed), Abbreviations: Ap, apical tip; Cara, carapace; Chel, chelicera; Eye, eye; Fix R, fixed ramus; Free R, free ramus; Meso, mesosoma; Meta, Metasoma; Oc, ocelli; Opis, opisthosoma; Pr, prosoma/carapace; PreT, pretelson; Sl, swimming legs; Tel, telson; Wl, walking legs. 

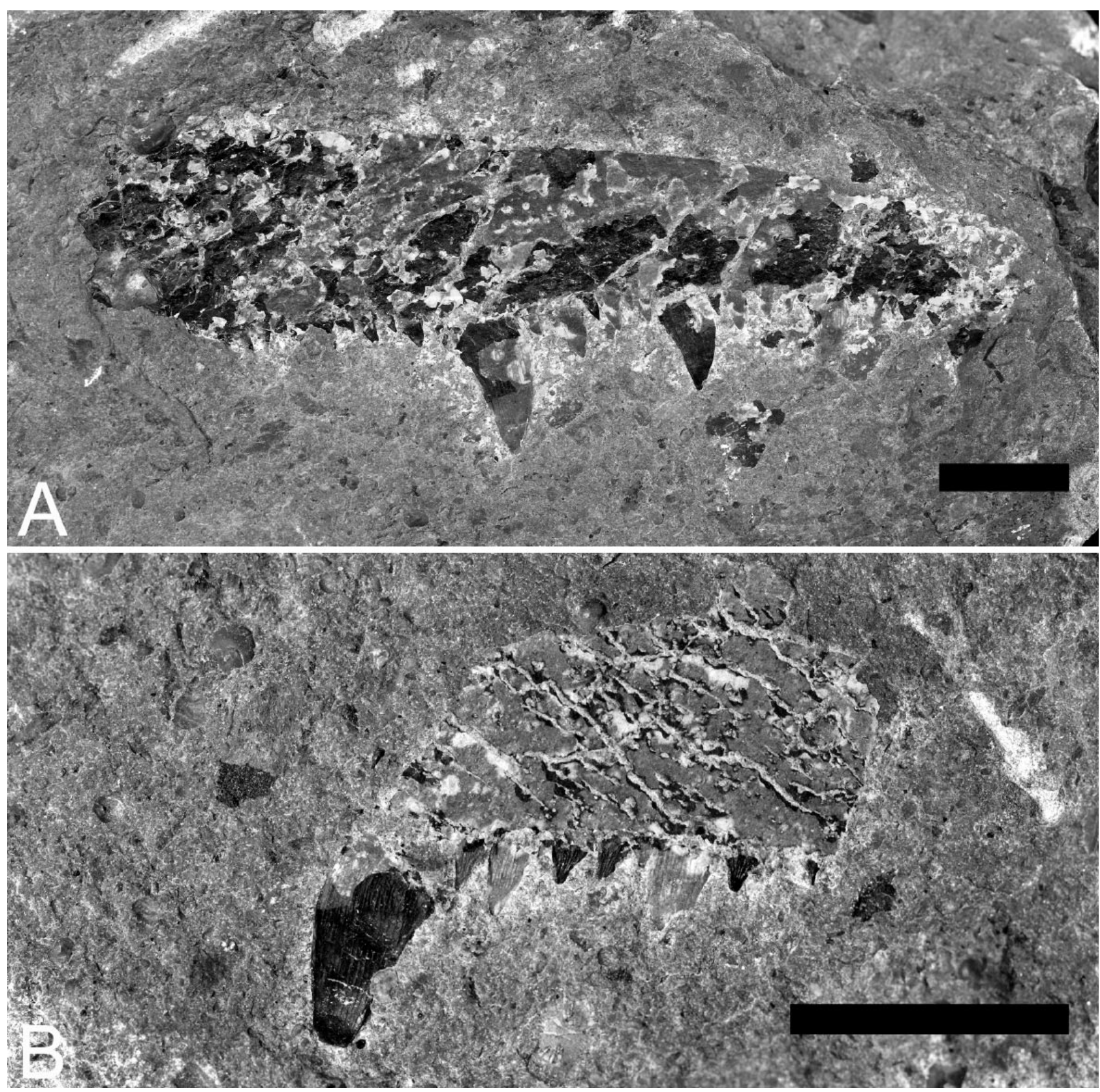

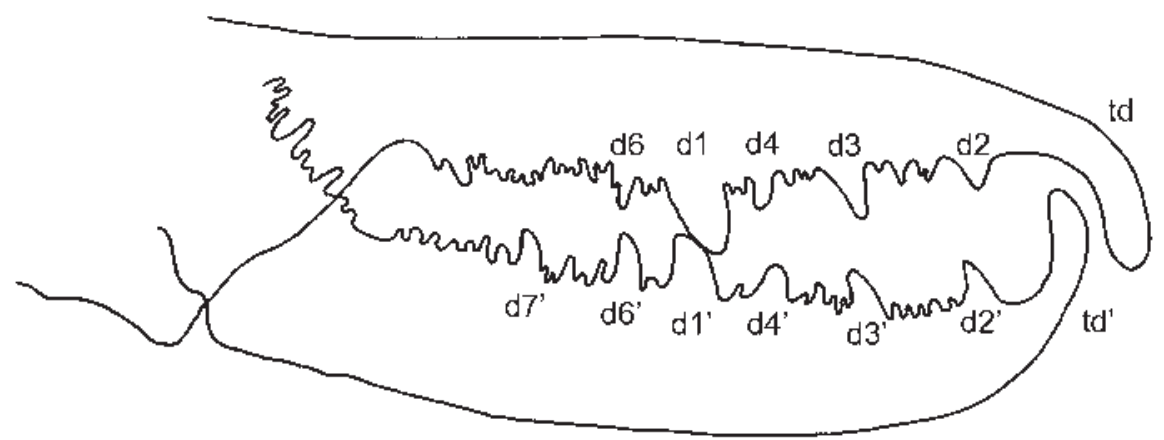

Fig. 5 (Above) Pterygotus anglicus Agassiz, 1844, Chelicera. A) NHM In.59039 showing principal denticles, scale $=1 \mathrm{~cm}$; B) NHM In.59032 showing curved terminal denticle, scale $=1 \mathrm{~cm}$. Campbellton Formation, Campbellton, New Brunswick.

Fig. 6 (Left) Reconstruction of chelicera of Pterygotus anglicus Agassiz, 1844, td, d1-d4, terminal and principal denticles on fixed ramus; td', d1'-d8', terminal and principal denticles on free ramus; $\mathrm{d} 1$ indicates primary denticle. 
ible. NHM In.59052 preserves a partial coxa, probably of a swimming leg, with six denticles visible on the gnathobase. NHM In.59059 and NMS 1897.51.9 are partial paddles (?) of a swimming leg. NHM In.18520 is a coxa from a walking leg (Fig. 7B). NMS 1897.51.5 and 1897.51.6 are part and counterpart of a coxa from a walking leg.
Opisthosoma: NHM In.59064 preserves an opisthosomal segment (Fig. 3A), possibly number 7. NHM In.59057 preserves partial opisthosomal segments 1-4 (Fig. 4A). NHM In.59056 preserves part of opisthosomal segments 1-7(?). NHM In.59060 preserves an opisthosomal plate in 3 parts. Two complete telsons are preserved, NHM In.59063a, b preserves part and

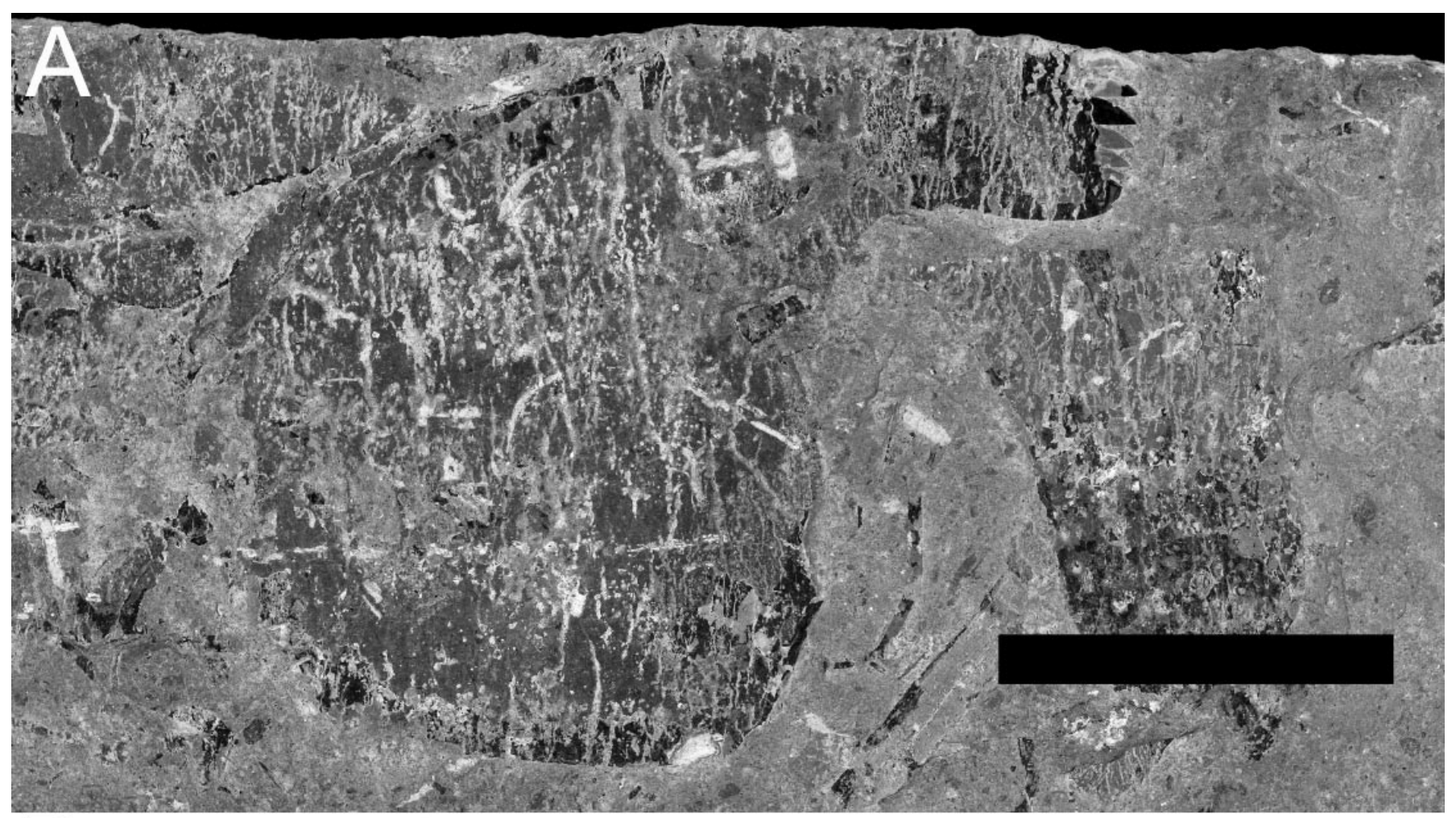

B

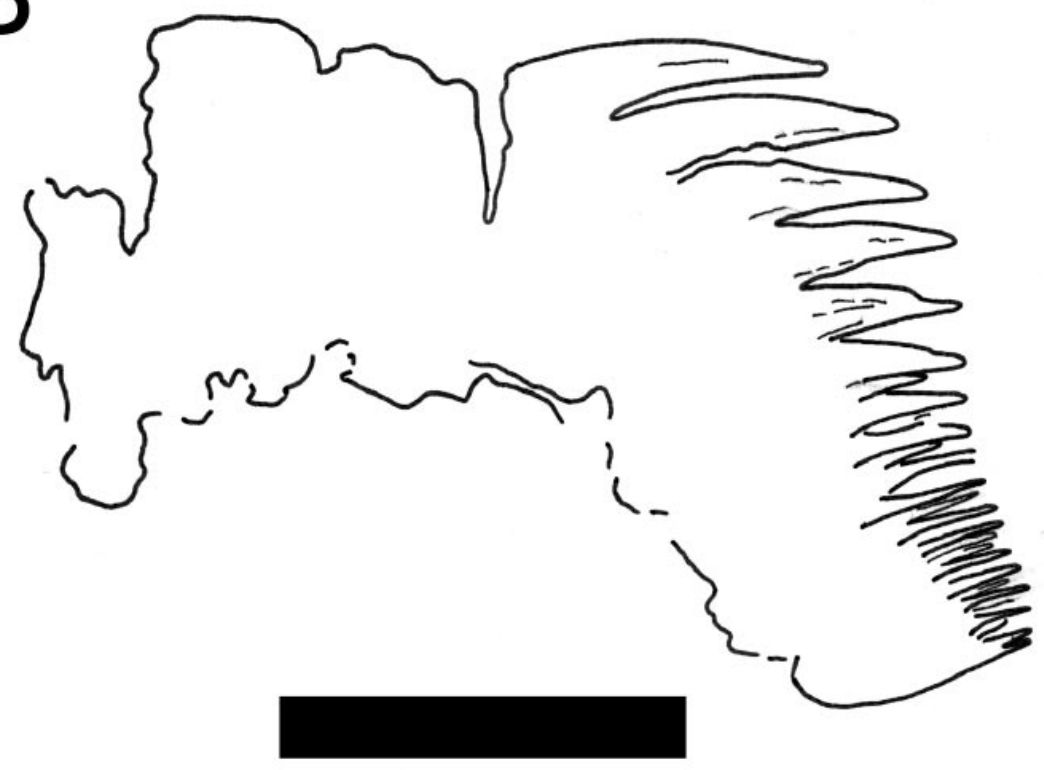

Fig. 7 Pterygotus anglicus Agassiz, 1844. A) Coxa of the swimming leg NHM In.59064, scale = $5 \mathrm{~cm}$; B) Camera lucida drawing of coxa of a walking leg NHM In.18520, scale $=1 \mathrm{~cm}$. Campbellton Formation, Campbellton, New Brunswick. 
counterpart of a telson $130 \mathrm{~mm}$ long and $90 \mathrm{~mm}$ wide (Fig. 8) and also the distal margin of the pretelson. NHM I.3210 is a telson, $180 \mathrm{~mm}$ long and $125 \mathrm{~mm}$ wide(Fig. 9). NMS 1897.51 .2 and 1897.51.12 may represent telson fragments.

Remarks: Based on measurements of the width of the prosoma and telson, and using body dimensions in Figure 4B, the pterygotids represented here ranged in length from about $75 \mathrm{~cm}$ to $120 \mathrm{~cm}$ from the anterior margin of the prosoma to the distal end of the opisthosoma. Characters observed on the carapace, chelicera and telson are consistent with Pterygotus anglicus Agassiz.

\section{CONCLUSION}

The depositional environment of the Campbellton Formation has been considered fluvial (Williams et al. 1985) or described as a coarsening-upward alluvial-lacustrine sequence (Rust et al. 1989; Gamba 1990; Wilson et al. 2004). A lagoon or estuary environment is likely represented (Miller 2007) since rare prasinophyte algae (tasmanitids) from the upper part of the section at Atholville (Fig. 2) indicate a marine connection (Blieck and Cloutier 2000). In the basal sediments outcropping at Campbellton, ostracods are abundant in the basal mudstone breccia and plant remains are common. The fish

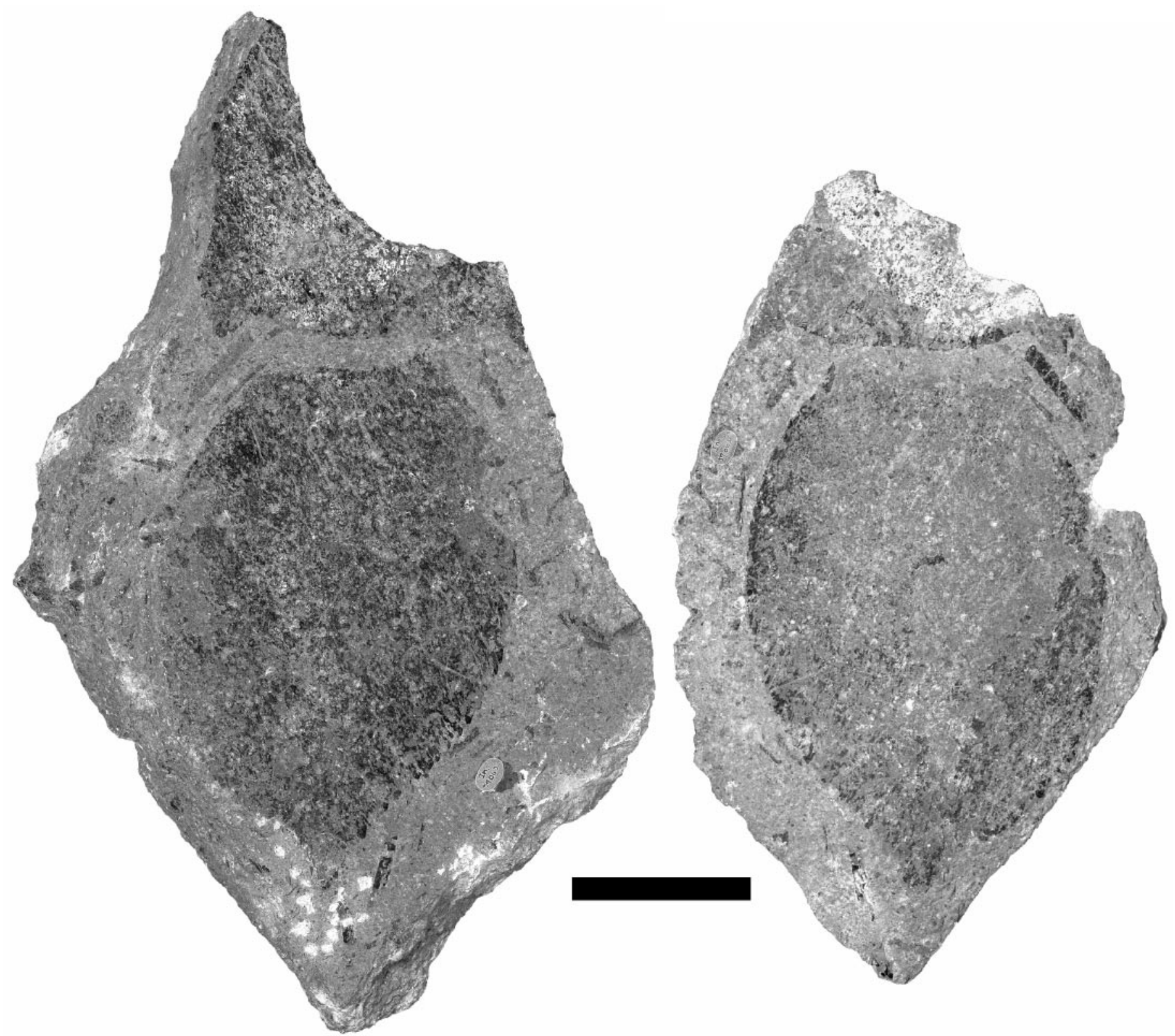

Fig. 8 Pterygotus anglicus Agassiz, 1844, distal pretelson and telson, part and counterpart NHM In.59063, scale $=5 \mathrm{~cm}$. Campbellton Formation, Campbellton, New Brunswick. 


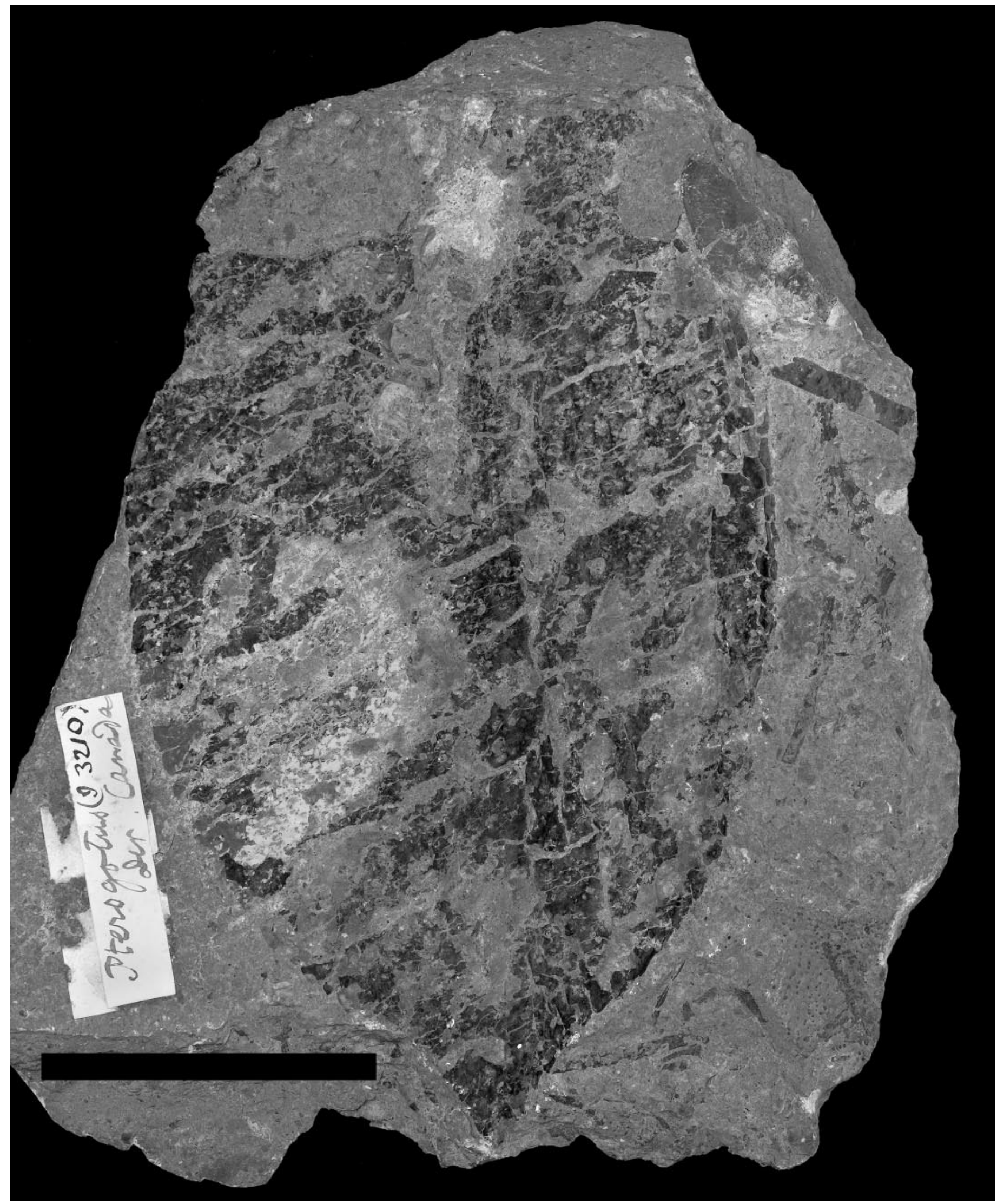

Fig. 9 Pterygotus anglicus Agassiz, 1844, distal telson NHM I.3210, scale $=5 \mathrm{~cm}$. Campbellton Formation, Campbellton, New Brunswick. 
assemblage found in the breccia and the mudstone containing the pterygotids from the Campbellton locality includes two ostracoderms, Yvonaspis campbelltonensis and Y. jexi (Pageau 1969a; Belles-Isles 1989), three placoderms Phlyctaenius acadicus, P. atholi, and P. stenosus (Young 1983), and two acanthodians Mesacanthus semistriatus and Cheiracanthus? costellatus (Pageau 1969a). 'Gyracanthus'(?) incurvus (Denison 1979) is considered as probably being a stem group gyracanthid (Turner et al. 2005). Two sharks, Doliodus problematicus (Woodward 1892; Miller et al. 2003; Turner 2004; Turner and Miller 2005a) and Protodus jexi (Woodward 1892; Turner and Miller 2005b) are also found at Campbellton. Spines of Climatius latispinosus (Whiteaves 1881) are common, although its position as an acanthodian is currently under review as it is most likely chondrichthyan (Miller et al. 2003). Spines identified as Ctenacanthus ornatus, are of uncertain affinity. Turner and Miller (2003) suggested that in this lowest part of the Campbellton Formation volcanic mudflows or lahars inundated coastal waters killing plants and animals, perhaps in a single event, leaving their remains in a chaotic mess. Fossil preservation supports an interpretation of rapid burial as some cephalaspids in collections of the Natural History Museum, London and the National Museums of Scotland include the headshield and the post-cranial body. Relatively complete acanthodians are known from the National Museums of Scotland collection and a three-dimensionally preserved acanthodian in the New Brunswick Museum collection (R. Cloutier, personal communication, 2004) was recovered from the basal breccia. Whether the deposits represent a lahar or not, the basal breccia exposed at Campbellton is a mudflow filled with a jumble of fossils and rhyolite fragments infilling fissures in the underlying rhyolite. The deposit seems to have been laid down over a limited geographical area. The Atholville beds outcrop sporadically along the Restigouche River shoreline and under the river from Campbellton to Atholville (Fig. 1B). Slumping, artificial fill, and gravel covered beaches have prevented measurement of a complete section and an adequate palaeoenvironmental interpretation.

Pterygotus anglicus from the Atholville locality (Miller 2007) occurs higher in the section in a relatively unfossiliferous mudstone (Fig. 2), with only occasional to rare plant fragments and few ostracods. P. anglicus has also been found in a siltstone within a cross-bedded sandstone-siltstone unit (Fig. 2). The most complete specimens at Atholville are found in association with sparse cephalaspid and placoderm remains, relative to the Campbellton locality, along with rare acanthodian spines and the remains of only one shark species, Doliodus problematicus (Miller et al. 2003).

Pterygotids are believed to have had a wide environmental range (Plotnick and Baumiller 1988; Chlupáč 1994) with species of Pterygotus occurring from freshwater to marine benthic assemblage 5. At Early Devonian sites in the Scottish Midland Valley, fish beds belonging to the Arbuthnott Group are considered lacustrine. There, P. anglicus occurs with acanthodians (Mesacanthus, Ischnacanthus, and Euthacanthus) and ostracoderms (Cephalaspis pagei) and may have spent its whole life in freshwater, since the full size range of $P$. anglicus individuals are found in the lake beds (Trewin and Davidson 1996; Braddy 2000, 2001). In the Campbellton Formation $P$. anglicus accompanies sharks and placoderms, indicating part of its life cycle may have been spent in brackish estuaries or lagoons. The brackish shoreline environments may have provided a suitable site for moulting. Poschmann and Tetlie (2006) suggested a pterygotid found in New York State, Acutiramus macrophthalmus, may have inhabited different environments depending on the age of the animal. They surmised that solitary, medium-sized individuals represented a marine phase of the life cycle, while in lagoons numerous small individuals found with mature adults might represent a nursery. Braddy (2001) proposed a 'mass-moult-mate' hypothesis in which eurypterids migrated en masse into nearshore and marginal environments such as lagoons to moult and mate and that they probably required a quiet, current-free place to moult. The Atholville beds may represent part of a continuum of environments inhabited by Pterygotus anglicus, from freshwater to marine. Although a range of sizes of individuals occurs in the Campbellton Formation the total number represented is still small, perhaps less than a dozen animals.

\section{ACKNOWLEDGEMENTS}

Thanks to Andrew Ross (Natural History Museum, London) and Jean Dougherty (Geological Survey of Canada) for arranging specimen loans and Lyall Anderson and Roberta Paton (National Museums of Scotland) for their hospitality and collections access. Erik Tetlie(Yale University) provided help with early phases of this project and with references. Photographs are courtesy of the Natural History Museum, London. Gwyneth Campling, Head of NHM Image Resources in London and her staff, provided photographs of the NHML specimens. Thanks also to Olga Afanassieva, Diane Buhay, Richard Cloutier, Steve Cumbaa, Richard Day, Patricia Gensel, Steve McCutcheon, Jeff McGovern, Sasha Miller, Norman Parent, Sue Turner, Jo Vergossen and Reg Wilson for assistance in the field. Reviewers Erik Tetlie and David Rudkin provided helpful suggestions to improve the manuscript as did the editor Ron Pickerill. Part of this work was supported by a Sylvester-Bradley Award from The Palaeontological Association and by a grant from the New Brunswick Environmental Trust Fund to study significant fossil sites in New Brunswick.

\section{REFERENCES}

Agassiz, J.L.R. 1839. Fishes of the Upper Ludlow rock. In The Silurian System, Part 1. Founded on geological researches in the counties of Solop, Hereford, Radnor, Montgomery, Caermarthen, Brecon, Pembroke, Monmouth, Gloucester, Worcester, and Stafford: with descriptions of the coal-fields and overlying formations. Edited by R.I. Murchison. London, John Murray, pp. 605-607. 
Agassiz, J.L.R. 1844. Monographie des poissons fossiles du vieux grès rouge, ou système dévonien(Old Red Sandstone) des Iles Britanniques et de Russie. Jent et Gassman, Neuchatel. $171 \mathrm{p}$.

Belles-Isles, M. 1989. Yvonaspis, nouveau genre d'Osteostraci (Vertebrata, Agnatha) du Dévonien (Emsien-Eifelien) des Grès de Gaspé(Québec, Canada). Canadian Journal of Earth Sciences, 26, pp. 2396-2401.

Blieck, A., AND Cloutier, R. 2000. Biostratigraphical correlations of Early Devonian vertebrate assemblages of the Old Red Sandstone Continent. In Palaeozoic vertebrate biochronology and global marine/non-marine correlation. Final Report of IGCP 328 (1991-1996). Edited by A. Blieck and S. Turner. Courier Forschungsinstitut Senckenberg, 223, pp. 223-269.

Bolton, T.E. 1966. Catalogue of the Type Invertebrate Fossils of the Geological Survey of Canada, Volume III. Geological Survey of Canada, Ottawa. 203 p.

Bourque, P.-A., Desbiens, S., And Gensel, P.G. 2005. Silurian-Devonian Biota and Paleoenvironments of Gaspé Peninsula and Northern New Brunswick. North American Paleontology Conference 2005, Field Guide, NAPC 2005, Halifax, Nova Scotia. 143 p.

BRAdDY, S.J. 2000. Eurypterids from the Early Devonian of the Midland Valley of Scotland. Scottish Journal of Geology, 36, pp. 115-122.

BRADDY, S.J. 2001. Eurypterid palaeoecology: palaeobiological, ichnological and comparative evidence for a 'massmoult-mate' hypothesis. Palaeogeography, Palaeoecology, Palaeoclimatology, 172, pp. 115-132.

Chlupáč, I. 1994. Pterygotid eurypterids (Arthropoda, Chelicerata) in the Silurian and Devonian of Bohemia. Journal of the Czech Geological Society, 39, pp. 147-162.

Ciurca, S.J. JR., And Tetlie, O.E. 2007. Pterygotids (Chelicerata; Eurypterida) from the Silurian Vernon Formation, New York. Journal of Paleontology, 81, pp. 725-736.

Clarke, J.M., ANd Ruedemann, R. 1912. The Eurypterida of New York. Memoirs of the New York State Museum, 14, Vol. 1 and $2.628 \mathrm{p}$.

Copeland, M.J., ANd Bolton, T.E. 1960. The Eurypterida of Canada. Bulletin of the Geological Survey of Canada, 60, pp. 13-47.

Denison, R.H. 1979. Pt 5 Acanthodii. In Handbook of Paleoichthyology. Edited by H.-P. Schultze. Gustav Fischer Verlag, Stuttgart. $62 \mathrm{p}$.

Dineley, D.L., AND Williams, B.P.J. 1968. The Devonian continental rocks of the Lower Restigouche River, Quebec. Canadian Journal of Earth Sciences, 5, pp. 945-953.

Dunlop, J.A., Braddy, S.J., and Tetlie, E. 2002. The Early Devonian eurypterid Grossopterus overathi (Gross, 1933) from Overath, Germany. Mitteilungen aus dem Museum für Naturkunde in Berlin, Geowissenschaftliche Reihe, 5, pp. 93-104.

ELLS, R.W. 1883. Report on the Geology of northern and eastern New Brunswick and the north side of the Bay of
Chaleurs. Geological Survey of Canada, Report of Progress, 1880-81-82, pp. 1D-24D.

GамвA, C.A. 1990. Sedimentological and tectonic implications of the Point la Nim and Campbellton formations, western Chaleur Bay, Maritime Canada. Unpublished M.Sc. thesis, University of Ottawa, Ottawa, Ontario. 249 p.

Gensel, P.G., AND AlbRight, V.M. 2006. Leclercqia complexa from the Early Devonian (Emsian) of northern New Brunswick, Canada. Review of Palaeobotany and Palynology, 142, pp. 103-121.

Gensel, P.G., And Andrews, H.N. 1984. Plant Life in the Devonian. Praeger, New York. 380 p.

Gensel, P.G., Chaloner, W.G., ANd Forbes, W.H. 1991. Spongiophyton from the late Lower Devonian of New Brunswick and Quebec, Canada. Palaeontology, 34, pp. 149-168.

Huxley, T.H., and Salter, J.W. 1859. On the anatomy and affinities of the genus Pterygotus and description of new species of Pterygotus. Memoirs of the Geological Survey of the United Kingdom, Monograph 1.105 p.

Jones, T.R. 1889. Notes of the Palaeozoic bivalved Entomostraca No. XXVII. On some North American (Canadian) species. Annals and Magazine of Natural History, 6, pp. 373-387.

KJellesvig-Waering, E.N. 1961. The Silurian Eurypterida of the Welsh Borderland. Journal of Paleontology, 35, pp. 789-835.

KJellesvig-Waering, E.N. 1964. A synopsis of the family Pterygotidae Clarke and Ruedemann, 1912 (Eurypterida). Journal of Paleontology, 38, pp. 331-361.

McGregor, D.C. 1973. Lower and Middle Devonian spores of eastern Gaspé, Canada. I. Systematics. Palaeontographica Abteilung B, 142, pp. 1-77.

McGregor, D.C. 1977. Lower and Middle Devonian spores of eastern Gaspé, Canada. II. Biostratigraphic significance. Palaeontographica Abteilung B, 163, pp. 111-142.

MilLer, R.F. 1996. Note on Pterygotus anglicus Agassiz (Eurypterida: Devonian) from the Campbellton Formation, New Brunswick. Atlantic Geology, 32, pp. 95-100.

Miller, R.F. 2007. Pterygotus anglicus Agassiz (Chelicerata: Eurypterida) from Atholville, Lower Devonian Campbellton Formation, New Brunswick, Canada. Palaeontology 50, pp. 981-999.

Miller, R.F., Cloutier, R., And Turner, S. 2003. The oldest chondrichthyan from the Early Devonian period. Nature, 425, pp. 501-504.

New Brunswick Department of Natural Recources 2007. Lexicon Database: Lexicon of the Bedrock Nomenclature of New Brunswick Stratigraphy. URL <http://www.gnb.ca/ 0078/minerals/Bedrock_Nomenclature_NB-e.asp $>$, September 2007.

OGG, J.G. 2004. Status of Divisions of the International Geologic Time Scale. Lethaia, 37, pp. 183-199.

Pageau, Y. 1968. Nouvelle faune ichthyologique du Dévonien 
moyen dans les Grès de Gaspé (Québec). I. Géologie et écologie. Naturaliste Canadien, 95, pp. 1459-1497.

Pageau, Y. 1969a. Nouvelle faune ichthyologique du Dévonien moyen dans les Grès de Gaspé (Québec). II. Morphologie et systématique. Première section: A. Euryptérides, B. Ostracodermes, C. Acanthodiens et sélaciens. Naturaliste Canadien, 96, pp. 399-478.

Pageau, Y. 1969b. Nouvelle faune ichthyologique du Dévonien moyen dans les Grès de Gaspé (Québec). II. Morphologie et systématique. Deuxième section: Arthrodires: Dolicothoraci. Naturaliste Canadien, 96, pp. 805-889.

Plotnick, R.E., ANd Baumiller, T.K. 1988. The pterygotid telson as a biological rudder. Lethaia, 21, pp. 13-27.

Poschmann, M., and Tetlie, O.E. 2006. On the Emsian (Lower Devonian) arthropods of the Rhenish Slate Mountains: 5. Rare and poorly known eurypterids from Willwerath, Germany. Paläontologische Zeitschrift, 80, pp. 325-343.

Richardson, J.B., AND McGregor, D.C. 1986. Silurian and Devonian spore zones of the Old Red Sandstone continent and adjacent regions. Bulletin of the Geological Survey of Canada, $364.79 \mathrm{p}$.

Rust, B.R., Lawrence, D.A., And Zaitlin, B.A. 1989. The sedimentology and tectonic significance of Devonian and Carboniferous terrestrial successions in Gaspé, Quebec. Atlantic Geology, 25, pp. 1-13.

Shear, W., Gensel, P.G., ANd Jeram, A. 1996. Fossils of large terrestrial arthropods from the Lower Devonian of Canada. Nature, 384, pp. 555-557.

Størmer, L. 1936. Eurypteriden aus dem Rheinischen Unterdevon. Abhandlungen der Preußischen Geologischen Landesanstalt, Heft 175, pp. 1-74.

TetLIE, O.E. 2007. Distribution and dispersal history of Eurypterida (Chelicerata). Palaeogeography, Palaeoclimatology, Palaeoecology, 252, pp. 557-574.

Tollerton, V.P.JR. 1989. Morphology, taxonomy, and classification of the Order Eurypterida Burmeister, 1843. Journal of Paleontology, 63, pp. 642-657.

Traquair, R.H. 1890. Notes on the Devonian fishes of Scaumenac Bay and Campbelltown in Canada. Geological Magazine, 7, pp. 15-22.

TraquaIR, R.H. 1893. Notes on the Devonian Fishes of Campbelltown and Scaumenac Bay in Canada - No. 2. Geological Magazine, 10, pp. 145-149.

Trewin, N.H., ANd Davidson, R.G. 1996. An Early Devonian lake and its associated biota in the Midland Valley of Scotland. Transactions of the Royal Society of Edinburgh: Earth Sciences, 86, pp. 233-246.

TURNER, S. 2004. Early vertebrates: analysis from microfossil evidence. 65-94. In Recent Advances in the Origin and Early Radiation of Vertebrates. Edited by G. Arattia, M.V.H., Wilson, and R. Cloutier. Verlag, Dr. Friedrich Pfeil, Müenchen, Germany. 703 p.

Turner, S., AND Miller, R.F. 2003. IGCP 491: Devonian Disaster lahars and lagoons in northern New Brunswick.
In The Rhynie Hot Spring System: Geology, Biota and Mineralisation, Programme and Abstracts, p. 18.

Turner, S., ANd Miller, R F. 2005a. New ideas about old sharks. American Scientist, 93, pp. 244-252.

Turner, S., And Miller, R.F. 2005b. Protodus jexi Woodward 1892, an Early Devonian shark from Canada. North American Paleontology Convention 2005, Programme and Abstracts, p. 116.

Turner, S., Burrow, C.J., And Warren, A. 2005. Gyracanthides hawkinsi sp. nov. (Acanthodii, Gyracanthidae) from the Lower Carboniferous of Queensland, Australia, with a review of gyracanthid taxa. Palaeontology, 48, pp. 963-1006.

Waterston, C.D. 1964. Observations on pterygotid eurypterids. Transactions of the Royal Society of Edinburgh, 66, pp. 9-33.

Whiteaves, J.F. 1881. On some fossil fishes, Crustacea and Mollusca from the Devonian rocks at Campbellton, New Brunswick, with description of five new species. Canadian Naturalist and Quarterly Journal of Science, 10, pp. 93101.

Whiteaves, J.F. 1889. Illustrations of the fossil fishes of the Devonian rocks of Canada, Part II. Transactions of the Royal Society of Canada, 6, pp. 77-96.

Whiteaves, J.F. 1899. The Devonian System in Canada. American Geologist, 24, pp. 210-221.

Williams, G.L., FyfFe, L.R., Wardle, R.J., Colman-Sadd, S.P., AND BoEHNER, R.C. 1985. Lexicon of Canadian Stratigraphy, Volume VI, Atlantic Region. Canadian Society of Petroleum Geologists, Calgary. 572 p.

WiLson, H.M. 2006. Juliformian millipedes from the Lower Devonian of Euramerica: implications for the timing of millipede cladogenesis in the Paleozoic. Journal of Paleontology, 80, pp. 638-649.

Wilson, R.A., Burden, E.T., Bertrand, R., Asselin, E., and McCracken, A.D. 2004. Stratigraphy and tectonosedimentary evolution of the Late Ordovician to Middle Devonian Gaspé Belt in northern New Brunswick: evidence from the Restigouche area. Canadian Journal of Earth Sciences, 41, pp. 527-551.

Woodward, H. 1866-78. A Monograph of the British Fossil Crustacea belonging to the Order Merostomata. Memoir of the Palaeontographical Society, London. 263 p.

WooDWARD, A.S. 1889. Acanthodian fishes from the Devonian of Canada. Annals and Magazine of Natural History, 4, pp. 183-184.

Woodward, A.S. 1892. On the Lower Devonian Fish-Fauna of Campbellton, New Brunswick. Geological Magazine, 9, pp. 1-6.

Young, V.T. 1983. Taxonomy of the arthrodire Phlyctaenius from the Lower or Middle Devonian of Campbellton, New Brunswick, Canada. Bulletin of the British Museum (Natural History) Geology Series, 37, pp. 1-35.

Editorial responsibility: Ron K. Pickerill 